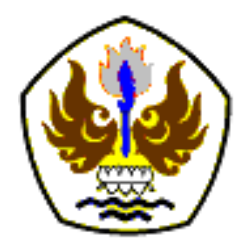

INFOMATEK

Volume 18 Nomor 2 Desember 2016

\title{
MODEL INTERAKSI APLIKASI WEB PADA TEKNOLOGI JAVA
}

\author{
Ade Sukendar $\left.{ }^{*}\right)$ \\ Program Studi Teknik Informatika \\ Fakultas Teknik - Universitas Pasundan
}

\begin{abstract}
Abstrak: Aplikasi web adalah aplikasi yang berjalan dengan menggunakan koneksi jaringan menggunakan protokol HTTP. Interaksi aplikasi web dimulai ketika pengguna meminta (request) ke server sampai server memberikan tanggapan (response) kepada pengguna. Setiap interaksi yang terjadi akan mengakses bagian program, semakin lingkupnya besar maka program yang terdapat pada aplikasi akan semakin banyak pula. Penelitian ini akan melakukan studi terhadap model interaksi web pada teknologi Java dan keterkaitannya dengan proses perawatan terhadap model interaksi yang digunakan. Pada penelitian ini melakukan studi literatur dan melakukan berbagai eksplorasi tehadap penelitian-penelitian serupa yang sudah dilakukan sebelumnya berdasarkan referensi. Hasil akhir dari penelitian ini yaitu memberikan perbandingan setiap model interaksi yang digunakan pada tingkatan program dengan maupun tanpa framework.
\end{abstract}

Kata kunci: Aplikasi Web, Model Interaksi, Java Web, Perawatan

\section{PENDAHULUAN}

\section{Latar Belakang}

Aplikasi web dapat dieksekusi karena adanya interaksi antara pengguna dan server menggunakan protokol HTTP (Hyper Text Transfer Protocol). Dalam interaksi tersebut, pengguna akan meminta layanan ke server dan selanjutnya server memberikan layanan tanggapan yang diminta oleh pengguna (Pressman [1]). Pengguna meminta layanan ke server untuk melakukan fungsi atau proses tertentu pada halaman web yang ditempilkan di web browser. Permintaan data dari pengguna akan dikirimkan lewat jaringan

*) ade.sukendar@unpas.ac.id dengan menggunakan protokol HTTP ke server atau dikenal dengan nama web server. Kemudian web server akan memproses permintaan dari pengguna untuk memproses fungsi tertentu dan kemudian mengambil halaman web yang diminta. Setelah itu, web server memberikan response ke pengguna berupa kode-kode HTML (Hypertext Markup Language) ataupun dokumen markup language yang akan membentuk halaman web di web browser, sehingga pengguna bisa mendapatkan fungsi dan halaman web yang diinginkan. Struktur program aplikasi web terdiri dari program untuk tampilan aplikasi web dalam bentuk bahasa markup dan business logic sebagai fungsional dari aplikasi 
tersebut [1]. Program untuk tampilan aplikasi web khusus untuk menampilkan antarmuka ke pengguna sedangkan program business logic berfungsi sebagai pemroses permintaan yang diminta oleh pengguna.

Seiring dengan perkembangan teknologi web, perubahan pengembangan aplikasi web ikut mengalami perubahan. Penambahan fitur, komponen, library dan lainnya akan ditambahkan ke program aplikasi web yang akan dibangun (Chung [2]). Dengan demikian, aplikasi web yang dibangun akan terus mengalami penambahan atau perubahan sehingga program menjadi bertambah besar dan rumit (Bereton [3]). Sehingga dibutuhkan suatu model yang dapat menangani hal tersebut, supaya aplikasi web yang dibangun bisa ditangani dengan mudah (Sukendar [4]).

\section{Identifikasi Masalah}

Berdasarkan dari latar belakang yang dijelaskan di atas, didapatkan beberapa identifikasi masalah sebagai berikut :

1. Model interaksi apa yang dapat diterapkan pada pengembangan aplikasi web berbasis Java?

2. Bagaimana implementasi model interaksi aplikasi web pada pengembangan aplikasi web berbasis Java dengan dan tanpa framework?

3. Bagaimana pengaruh implementasi model interaksi aplikasi web berbasis Java terhadap bagian-bagian program?

\section{Tujuan Penelitian}

Berikut ini merupakan tujuan dari penelitian yang dilakukan:

1. Mempelajari model interaksi aplikasi web pada teknologi Java.

2. Memahami dan membandingkan model interaksi aplikasi web pada teknologi Java.

3. Membuat aplikasi web berbasis teknologi Java berdasarkan model dan framework yang digunakan.

\section{METODOLOGI}

Pada penelitian ini terdiri dari tiga metode yaitu pengumpulan data, eksplorasi model interaksi dan implementasi program setiap model interaksi. Metode tersebut digunakan untuk mengetahui model interaksi dan implementasinya di lingkungan web berbasis Java yang diperlukan sebagai tahapan untuk menyelesaikan perancangan aplikasi pada penelitian ini (Gambar 1).

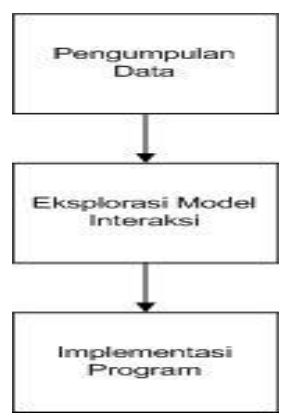

Gambar 1

Tahapan Penelitian 


\section{Pengumpulan Data}

Tahapan penelitian ini dilakukan pengumpulan data dengan melakukan studi literatur yang berkaitan dengan topik yang diangkat. Studi literatur yang dilakukan yaitu dengan dengan mencari informasi terkait dengan penelitian yang sedang dilakukan berdasarkan penelitian yang sudah pernah dilakukan berdasarkan paper, jurnal atau artikel.

\section{Eksplorasi Model Interaksi}

Tahapan penelitian ini dilakukan untuk mengetahui model interaksi aplikasi web pada teknologi Java. Pada tahapan ini akan meninjau lebih dalam terhadap bagian program aplikasi web. Bagian program tersebut yaitu program untuk antarmuka pengguna, business logic dan tempat penyimpanan data. Bagian program ini akan disesuaikan dengan model interaksi aplikasi web.

Setiap model interaksi akan diidentifikasi karakteristik dan penempatanya terkait dengan bagian program yang lain. Selain itu akan dikaitkan juga dengan fitur Java pada pengembangan aplikasi web. Sehingga setiap model mempunyai karakteristik yang berbeda. Selain itu, model interaksi yang diteliti terdiri dari dua yaitu model interaksi web tanpa dan dengan menggunakan framework.

Pada setiap model interaksi aplikasi web yang diteliti akan dibuatkan program-program kecil untuk mengetahui bagian-bagian pembentuk program. Selain bagian program dipergunakan juga diagram dan daftar file yang dapat mengidentifikasi setiap model interaksi yang sedang diteliti.

\section{LANDASAN TEORI}

\section{Aplikasi Web}

Aplikasi Web adalah perangkat lunak komputer yang terdiri dari kumpulan instruksi dan data yang menyediakan informasi dan fungsi bagi pengguna akhir [1]. Konten aplikasi web terdiri dari dua yaitu statis dan dinamis. Aplikasi web statis adalah halaman web yang tradisional dengan sifatnya tetap dan tidak bisa diubah, dalam kondisi yang sama halaman tersebut akan selalu tetap sama [5][6]. Permintaan dari banyak pengguna untuk halaman statis yang sama semuanya akan menerima hasil yang sama.

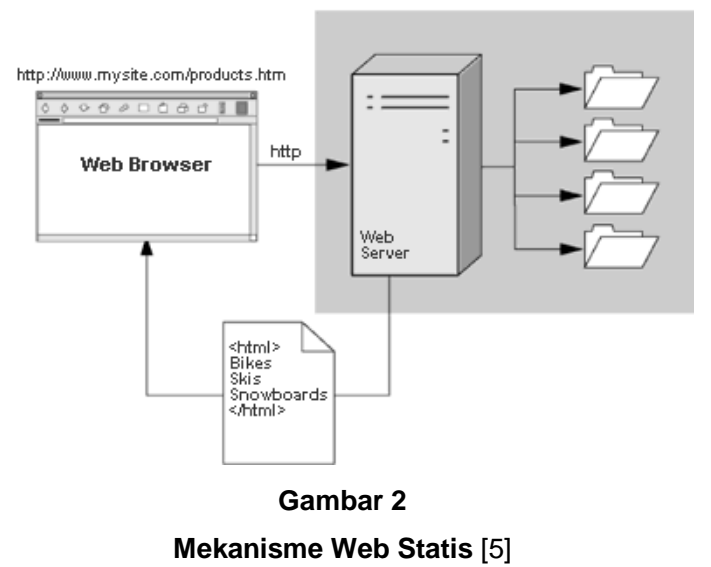

Pengkasesan halaman web statis, pengguna meminta halaman web dari server dan server 
memberikan tanggapan dengan mengirimkan file yang diminta oleh pengguna. Selanjutnya pengguna menerima halaman web yang berada di server. Halaman web dinamis merupakan halaman web yang dihasilkan sesuai dengan waktu permintaan dari pengguna, mengubah konten sesuai dengan kategori yang sudah ditentukan [5], (Horstmann [6]). Setiap request yang berbeda dari client akan menghasilkan halaman web yang berbeda pula, sehingga konten web yang dihasilkan akan dibuat on-the-fly (atau on-demand) berdasarkan permintaan dari pengguna. Sebagai contoh, halaman web yang menampilkan waktu sekarang adalah dinamis, karena konten halaman web menggambarkan waktu yang sekarang. Halaman web dinamis dibangkitkan oleh aplikasi server, menerima masukan dari pengguna dan kemudian memberikan tanggapan terhadap permintaan tersebut.

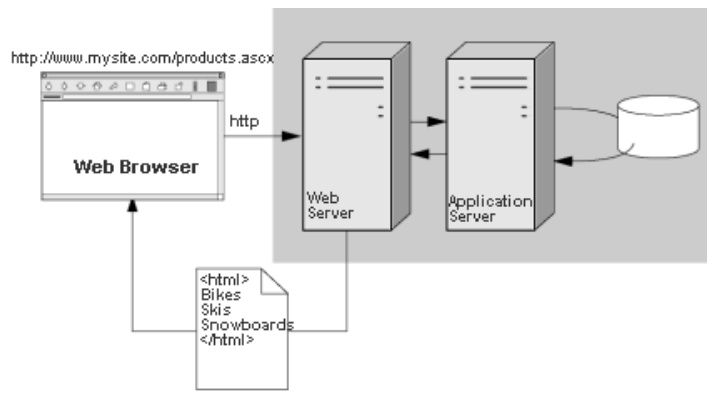

Gambar 3

Mekanisme Web Dinamis [5]

Pengguna melakukan permintaan ke server dengan menggunakan aplikasi web browser, kemudian web server akan menerima permintaan dan memberikan permintaan pengguna ke dalam aplikasi server untuk pemrosesan dengan keluaran berupa data dalam bentuk HTML dan kemudian dikembalikan ke web server. Web server akan mengirimkan tanggapan berupa hasil halaman HTML ke browser, dan halaman tersebut yang akan ditampilkan ke pengguna.

\section{Protokol HTTP}

HTTP merupakan kepanjangan dari Hipertext Transfer Protocol. HTTP memiliki sifat yang generic dan ringan, sehingga digunakan untuk mengirimkan teks Hypertext Markup Language (HTML) dan Extensible Markup Language (XML) (Jendrock [7]). HTTP merupakan protokol utama yang digunakan untuk mengrimkan informasi lewat World Wide Web.

HTTP merupakan protokol yang tidak memiliki keterhubungan dengan permintaan dari pengguna. Dengan kata lain, ketika pengguna melakukan permintaan ke server maka server akan memberikan tanggapan dan kemudian transaksi akan ditutup. Permintaan yang kedua dari pengguna yang sama secara keseluruhan merupakan transaksi baru, tidak ada keterkaitan dengan permintaan yang sebelumnya.

\section{Java Web}

Java Web berada pada lingkungan platform Java edisi enterprise atau disebut dengan 
Java Enterprise Edition (Java EE). Java EE adalah teknologi Java yang dirancang untuk memberikan solusi pengembangan aplikasi web dalam skala enterprise, merupakan suatu blue print dan sekumpulan API untuk pengembangan aplikasi enterprise berbasis Java (Falkner [8]), [9].

Java EE mempunyai tiga lapisan arsitektur terhadap sistem enterprise. Sistem yang mempunyai tiga lapisan atau lebih, membuktikan sistem tersebut lebih terukur dan fleksibel dibandingkan sistem client server. Sistem yang mempunyai berbagai lapisan yang telah dirancang dengan baik, setiap lapisan hanya akan bergantung pada lapisan yang berada dibawahnya. Misalnya perubahan pada suatu basis data tidak mengakibatkan terjadinya perubahan pada tampilan halaman web. Keterhubungan ketiga lapisan pada Java EE seperti terlihat pada gambar berikut [7]:

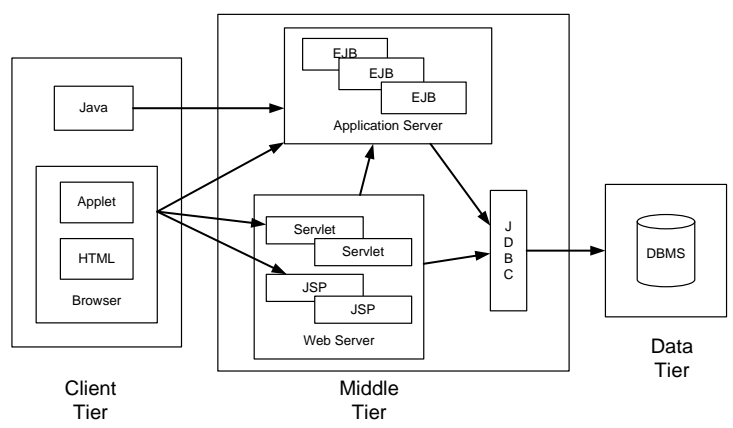

Gambar 4

Arsitektur Aplikasi Java EE
Berikut ini merupakan penjelasan dari tiga lapisan utama yang dimiliki Java EE:

a. Enterprise Information Sistem (EIS) yaitu lapisan yang juga disebut sebagai lapisan integrasi adalah lapisan yang terdiri dari sumber daya yang harus diakses oleh aplikasi Java EE dalam melakukan pekerjaannya, di dalamnya juga termasuk manajemen sistem basis data.

b. Middle tier yaitu lapisan yang terdiri dari objek bisnis yang dimiliki aplikasi dan menghubungkan sumber daya lapisan EIS. Komponen dari lapisan ini berada terpisah dari tampilan yang akan dipilih oleh user. Jika menggunakan EJB, maka lapisan ini akan dibagi menjadi dua bagian yaitu : EJB dan objek yang menggunakan EJB untuk mendukung tampilan.

c. User interface tier yaitu lapisan yang bertugas menampilkan objek bisnis pada middle tier kepada pengguna. Pada sebuah aplikasi web, lapisan ini terdiri dari servlets, helper class yang digunakan oleh servlet, dan komponen untuk menampilkan seperti halaman JSP.

\section{Komponen Aplikasi Java EE}

Platform Java EE menyediakan model-model komponen sebagai penyusunan aplikasi. Java EE memberikan kemudahan untuk membagi dan memecah sebuah aplikasi dengan menyusun komponennya kemudian mengintegrasikan menjadi sebuah aplikasi. 
Setiap komponen tersebut dieksekusi didalam sebuah kontainer.

Berikut ini merupakan komponen-komponen yang dimiliki oleh Java EE [7]:

a. Komponen client terdiri dari aplikasi client yang mengakses server Java EE dan biasanya diletakkan pada mesin yang berbeda dengan server. Komponen client terdiri dari JavaBean dan Applet.

b. Komponen aplikasi web terdiri dari komponen-komponen yang dijalankan pada server. Komponen aplikasi web terdiri dari servlet, JSP dan tag lib.

c. Komponen bisnis terdiri dari komponenkomponen bisnis yang dijalankan pada server. Komponen ini terdiri dari session bean, entity bean dan message driven bean.

\section{Model-View-Controller (MVC)}

Permasalahan desain yang ditangani oleh MVC secara sederhananya terdiri dari tiga fungsi utama yaitu [9]:

a. Mengelola data di tempat penyimpanan data.

b. Membangun layer presentasi untuk enduser.

c. Mengelola logika pengkondisian yang memutuskan screen mana yang akan ditampilkan ke pengguna, apa yang terjadi ketika tampil error; dan mengetahui bagaimana dan kapan data diubah.

Arsitektur MVC membagi aplikasi kedalaman tiga layer, yaitu model, view dan controller. Setiap layer mempuyai tugas dan tanggung jawab masing-masing, selain itu menangani tugas yang spesifik dan mempunyai tanggung jawab yang spesifik untuk layer yang lain.

\section{Organisasi Komponen Web}

Presentation Layer

Presentation Layer atau lapisan presentasi adalah lapisan yang berinteraksi dengan antarmuka pengguna. Lapisan ini berisi logika presentasi untuk menampilkan informasi kepada pengguna. Logika tersebut berinteraksi dengan antarmuka pengguna dan elemen-elemen berbasis web, seperti HTML, tag library ataupun XML. Lapisan ini menjelaskan bagaimana informasi ditampilkan kepada pengguna, bukan bagaimana informasi tersebut diambil atau dipilih oleh aplikasi.

\section{Controller Layer}

Controller layer atau lapisan controller adalah lapisan yang mengatur alur aplikasi dan memberikan service sebagai penghubung antara antarmuka pengguna (presentation layer) dan aplikasi (application layer). Lapisan controller berisi logika controller, yang berguna untuk menerima dan menerjemahkan HTTP 
request selanjutnya memutuskan langkah berikutnya dari aplikasi berdasarkan permintaan dari pengguna.

\section{Application Layer}

Application layer atau lapisan aplikasi adalah pusat dari aplikasi. Lapisan ini berisi logika aplikasi yang bertanggung jawab untuk proses aplikasi. Sebagai contoh, logika aplikasi di sistem registrasi berbasis web akan terdiri dari submit nama, mengecek validasi ke basisdata, tambahkan ke basisdata dan kemudian mengembalikan hasilnya.

\section{Framework Struts2}

Struts2 adalah framework yang menggunakan design pattern Model 2 menggunakan interface Filter (Kurniawan [10]), (Newton [11]), (Roughley [12]). Framework ini merupakan framework action-based dengan melakukan pemetaan URL request ke unit kerja yang disebut action. Design pattern Model-View-Controller di Struts2 mempunyai lima komponen utama, yaitu : actions, interceptors, nilai stack atau OGNL, tipe result dan results atau teknologi view.

Gambar 5 merupakan arsitektur high-level Struts2 (Turner [13]) yang terdiri dari Model, View dan Controller. Controller diimplementasikan dengan filter dispatch Struts2 sebagai interceptors, Model diimplementasikan dengan actions dan View sebagai kombinasi tipe result dan results. Stack dan OGNL memberikan thread, linking dan kemampuan integrasi dengan komponen lain.

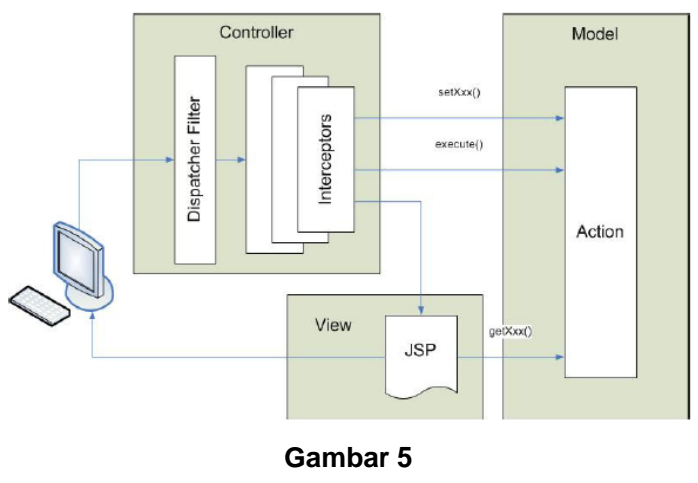

Arsitektur Framework Struts2

\section{EKSPLORASI}

Teknologi Servlet dan JSP merupakan solusi untuk pengembangan aplikasi web berbasis Java. Teknologi JSP merupakan perluasan dari teknologi Servlet untuk membangun aplikasi Web dengan menyatukan kode Java ke dalam halaman HTML (Wijono [14]). Teknologi JSP dibagi ke dalam dua organisasi komponen, pembagian tersebut berdasarkan peran dan tanggung jawab setiap komponen. Organisasi ini memisahkan antara logika presentasi dari logika aplikasi. Pemisahan organisasi ini sering disebut dengan Model 1 atau di sebut juga dengan page-centric [15].

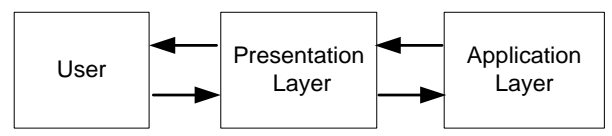

Gambar 6

Pemisahan Logika Presentasi 
Organisasi komponen yang kedua memisahkan logika controller dari logika presentasi. Pemisahan komponen ini disebut dengan Model 2. Model ini telah memisahkan komponen interaksi antara antarmuka pengguna, aplikasi dan interaksi pengguna. Model ini sering menunjukkan sebagai model berorientasi Servlet, karena dalam implementasinya Model 2 ini kebanyakan menggunakan halaman JSP dan Java Servlet [15].

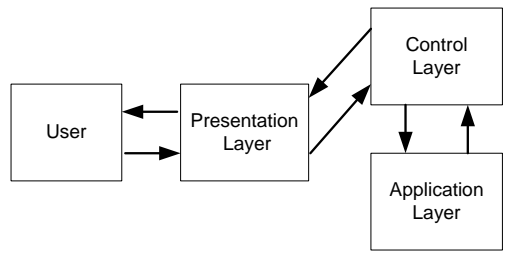

Gambar 7

Pemisahan Logika Controller

\section{Model 1}

\section{Arsitektur Model 1}

Arsitektur Model 1 yaitu kode fungsionalitas akan di simpan di manapun fungsionalitas diperlukan. Pendekatan ini sangat populer karena sederhana dan memberikan kecepatan dalam pengembangan aplikasi.

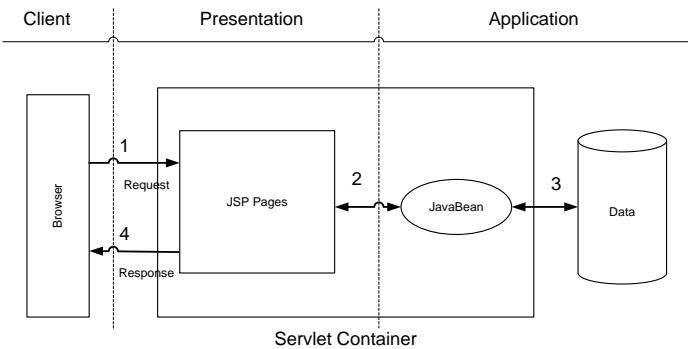

Gambar 8

Arsitektur Model 1
Aplikasi browser memberikan aplikasi web lewat sekumpulan halaman JSP sebagai lapisan presentasi. Sekumpulan halaman JSP tersebut diakses oleh user untuk diproses dari page pertama ke page yang berikutnya. Setiap halaman JSP dapat menggunakan JavaBean untuk melakukan proses aplikasi. Lapisan aplikasi ditangani oleh JavaBean untuk melakukan manipulasi ataupun mengolah informasi dari atau ke database. Hal yang perlu digarisbawahi dari arsitektur Model 1 ini bahwa setiap halaman JSP memproses input user oleh dirinya sendiri. Selain halaman JSP, sebuah servlet atau halaman HTML dapat mengantikan halaman tersebut.

\section{Model 2}

\section{Arsitektur Model 2}

Model 2 disebut juga MVC. Arsitektur Model ini mengambil manfaat dari kelebihan Servlet dan JSP. Servlet memiliki kelebihan dalam menangani tugas processing-intensive, sedangkan JSP memiliki kelebihan dalam presentasi data. Model 2 sudah melakukan pemisahan antara logika controller dan logika presentasi dalam lapisan yang berbeda. Logika controller akan berada di lapisan controller sedangkan logika presentasi akan tetap berada di dalam lapisan presentasi tanpa logika controller. Logika controller berfungsi untuk mengatur alur aplikasi yang akan di proses. Pemisahan Model 2 
menggunakan istilah design pattern MVC, yaitu : Model, View dan Controller. Komponen Controller bisa menggunakan salah satu dari Servlet atau Filter yang dirancang untuk menerima permintaan dan memberikan tanggapan ke pengguna yang berada di lapisan controller. Berikut di bawah ini gambar arsitekur model 2.

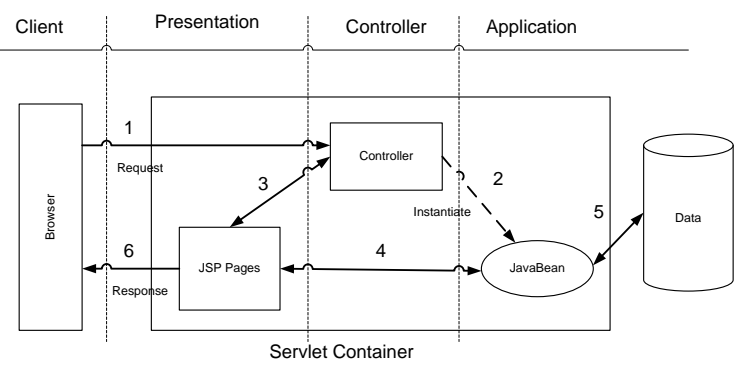

Gambar 9

Arsitektur Model 2

\section{IMPLEMENTASI PROGRAM}

\section{Model 1}

Implementasi Model 1 akan menggunakan kebutuhan pada tabel kebutuhan. Berikut di bawah ini adalah tabel kebutuhan aplikasi pengelolaan suplier.

Tabel 1

Kebutuhan Aplikasi Pengelolaan Suplier

\begin{tabular}{|l|l|l|}
\hline No & \multicolumn{1}{|c|}{ Kebutuhan } & \multicolumn{1}{|c|}{ Penjelasan } \\
\hline 1. & Simpan Suplier & $\begin{array}{l}\text { Kebutuhan aplikasi } \\
\text { untuk menyimpan } \\
\text { data suplier. }\end{array}$ \\
\hline 2. & Lihat Suplier & $\begin{array}{l}\text { Kebutuhan aplikasi } \\
\text { untuk melihat data } \\
\text { suplier sekaligus } \\
\text { pencarian suplier. }\end{array}$ \\
\hline 3. & Ubah Suplier & $\begin{array}{l}\text { Kebutuhan aplikasi } \\
\text { untuk mengubah } \\
\text { data suplier. }\end{array}$ \\
\hline
\end{tabular}

\begin{tabular}{|l|l|l|}
\hline No & Kebutuhan & \multicolumn{1}{|c|}{ Penjelasan } \\
\hline 4. & Hapus Suplier & $\begin{array}{l}\text { Kebutuhan aplikasi } \\
\text { untuk menghapus } \\
\text { data suplier. }\end{array}$ \\
\hline
\end{tabular}

Untuk mengetahui aliran proses dan objek yang terlibat dalam kebutuhan aplikasi maka digunakan diagram sequence. Berikut di bawah ini adalah gambar diagram sequence berdasarkan kebutuhan aplikasi di atas.

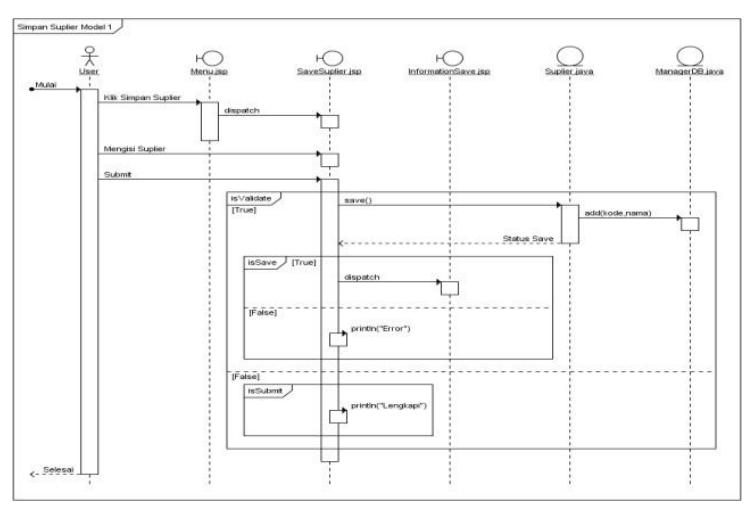

Gambar 10

Diagram Sequence Simpan Suplier Model 1

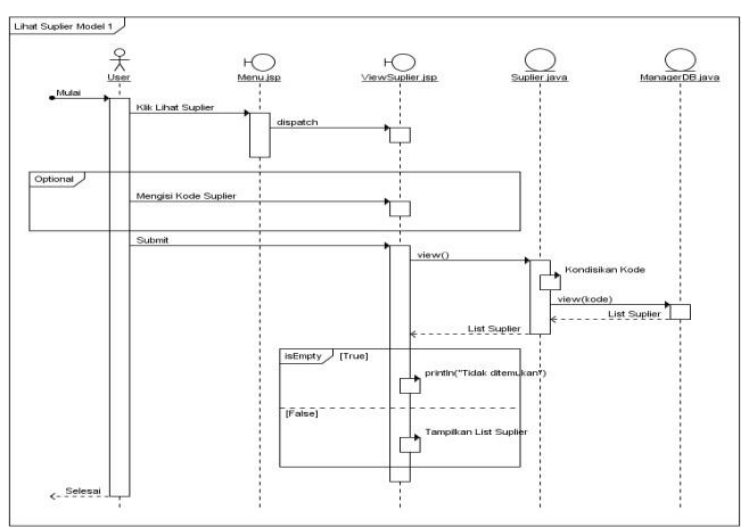

Gambar 11

Diagram Sequence Lihat Suplier Model 1 


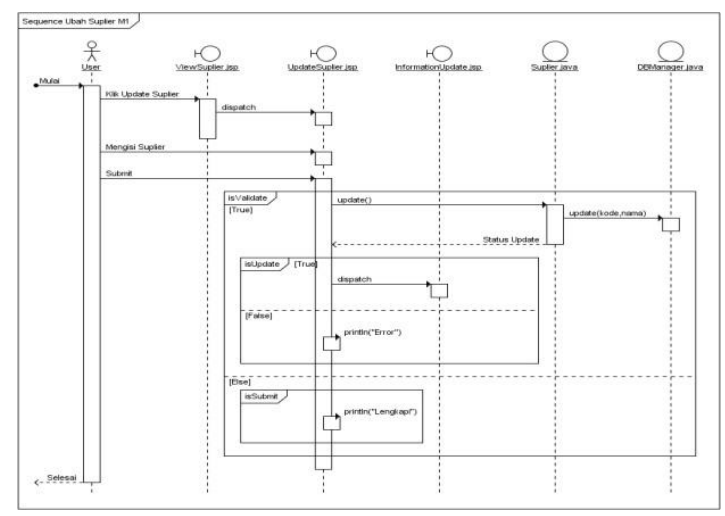

Gambar 12

Diagram Sequence Ubah Suplier Model 1

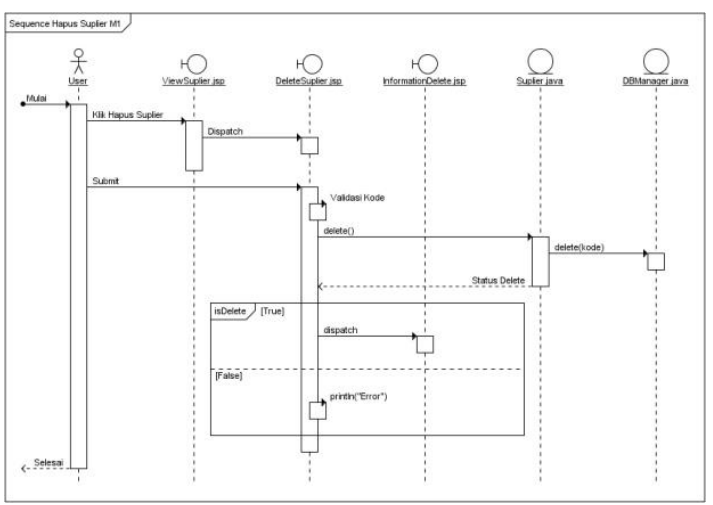

Gambar 13

Diagram Sequence Hapus Suplier Model 1

Berdasarkan diagram sequence diatas, contoh aplikasi tersebut memiliki sekumpulan halaman JSP dan JavaBean. Halaman JSP sebagai lapisan presentasi akan berinteraksi dengan pengguna, sedangkan JavaBean sebagai lapisan aplikasi melakukan pemrosesan aplikasi. Berikut ini daftar file aplikasi yang dibutuhkan sesuai dengan lapisan organisasi komponen Model 1.
Tabel 2

Daftar File Aplikasi Model 1

\begin{tabular}{|l|l|}
\hline \multicolumn{1}{|c|}{ Lapisan } & \multicolumn{1}{c|}{ File } \\
\hline \multirow{2}{*}{ Lapisan Presentasi } & $\begin{array}{l}\text { Menu.jsp } \\
\text { SaveSuplier.jsp } \\
\text { UpdateSuplier.jsp } \\
\text { DeleteSuplier.jsp } \\
\text { ViewSuplier.jsp } \\
\text { InformasiSave.jsp } \\
\text { InformasiUpdate.jsp } \\
\text { InformasiDelete.jsp }\end{array}$ \\
\hline Lapisan Aplikasi & $\begin{array}{l}\text { Suplier.java } \\
\text { ManagerDB.java }\end{array}$ \\
\hline
\end{tabular}

\section{Model 2}

Implementasi Model 2 akan menggunakan kebutuhan yang sama dengan Model 1 pada tabel kebutuhan $\mathrm{x}$. Berikut di bawah ini adalah gambar diagram sequence diagram berdasarkan kebutuhan aplikasi di atas dengan menggunakan Model 2.

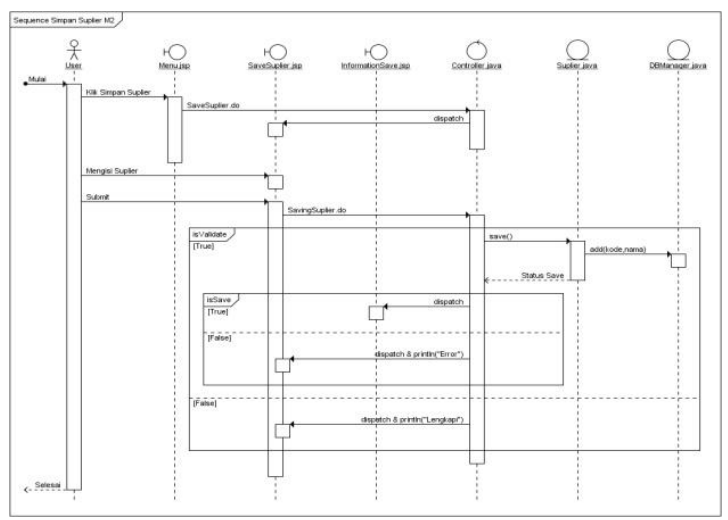

Gambar 14

Diagram Sequence Simpan Suplier Model 2 


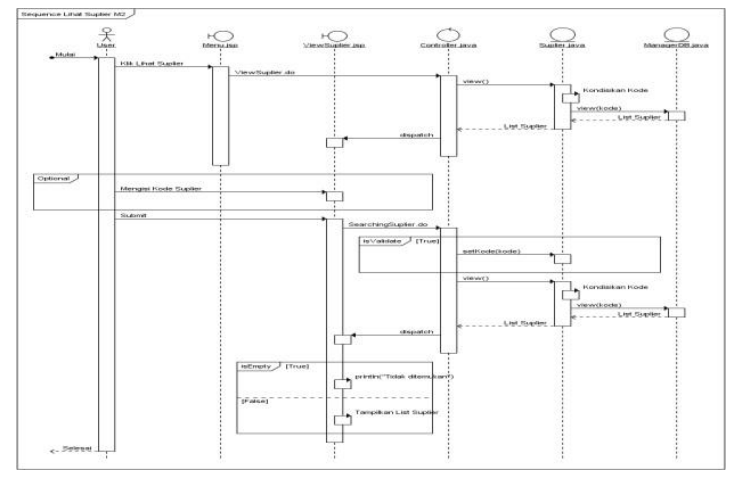

Gambar 15

Diagram Sequence Lihat Suplier Model 2

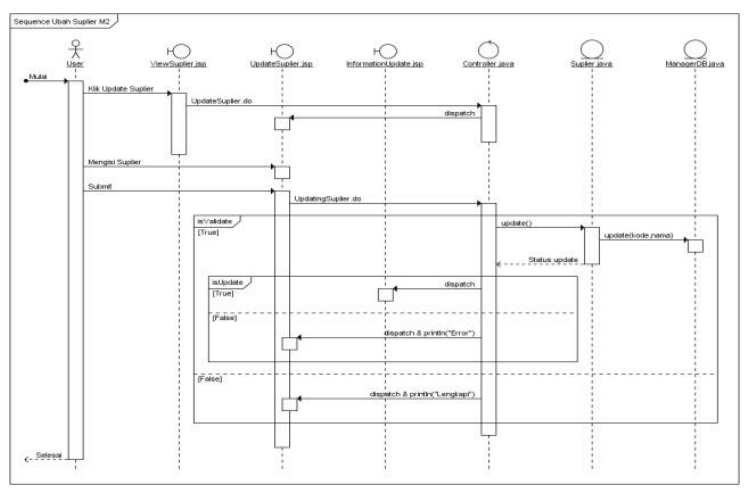

Gambar 16

Diagram Sequence Ubah Suplier Model 2

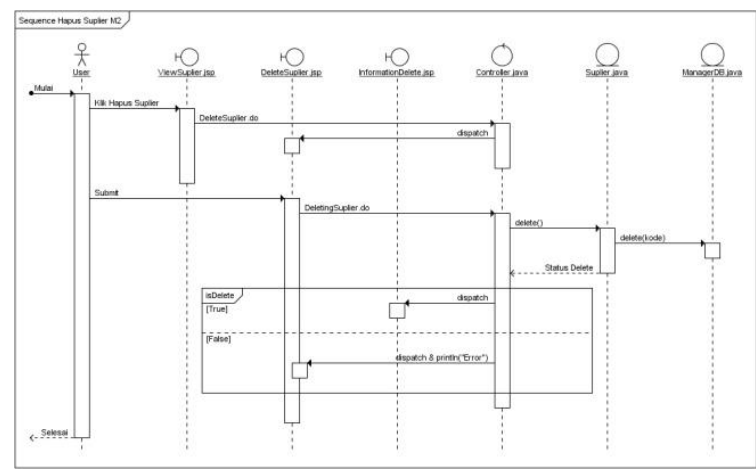

Gambar 17

Diagram Sequence Hapus Suplier Model 2
Diagram sequence di atas berbeda dengan diagram sequence Model 1, pada diagram tersebut mempunyai satu layer baru yaitu sebuah controller. Controller dibuat karena adanya pemisahan logika antara presentasi dan controller. Berikut ini daftar file aplikasi yang dibutuhkan sesuai dengan lapisan organisasi komponen Model 2.

Tabel 3

Daftar File Aplikasi Model 2

\begin{tabular}{|c|c|}
\hline Lapisan & File \\
\hline $\begin{array}{l}\text { Lapisan } \\
\text { Presentasi }\end{array}$ & $\begin{array}{l}\text { Menu.jsp } \\
\text { SaveSuplier.jsp } \\
\text { UpdateSuplier.jsp } \\
\text { DeleteSuplier.jsp } \\
\text { ViewSuplier.jsp } \\
\text { InformasiSave.jsp } \\
\text { InformasiUpdate.jsp } \\
\text { InformasiDelete.jsp }\end{array}$ \\
\hline $\begin{array}{l}\text { Lapisan } \\
\text { Controller }\end{array}$ & Controller.java \\
\hline $\begin{array}{l}\text { Lapisan } \\
\text { Aplikasi }\end{array}$ & $\begin{array}{l}\text { Suplier.java } \\
\text { ManagerDB.java }\end{array}$ \\
\hline
\end{tabular}

Berdasarkan tabel di atas, terlihat adanya lapisan controller yang digunakan untuk mengatur alur aplikasi. Lapisan tersebut hanya memiliki satu file yaitu Controller.java. Semua event dari pengguna akan ditangani oleh controller ini. 
Controller yang berada di lapisan controller dapat menggunakan kelas Servlet maupun interface Filter. Controller yang menggunakan kelas Servlet harus melakukan inheritance dari kelas HTTPServlet, sedangkan controller yang menggunakan interface Filter harus melakukan implement terhadap interface Filter.

\section{Pembahasan Model 1 dan Model 2}

Perbedaan yang pertama adalah alur model interaksi di dalam sistem. Perbedaan tersebut bisa di lihat Tabel 4.

Tabel 4

Perbandingan Alur Model Interaksi

\begin{tabular}{|l|l|}
\hline \multicolumn{1}{|c|}{ Model } & \multicolumn{1}{|c|}{ Interaksi } \\
\hline Model 1 & $\begin{array}{l}\text { User } \rightarrow \text { JSP } \rightarrow \text { JavaBean } \rightarrow \\
\text { Database } \rightarrow \text { JavaBean } \rightarrow \quad \text { JSP } \\
\rightarrow \text { User }\end{array}$ \\
\hline Model 2 & $\begin{array}{l}\text { User } \rightarrow \text { JSP } \rightarrow \text { Controller } \rightarrow \\
\text { JavaBean } \rightarrow \quad \text { Database } \\
\text { JavaBean } \rightarrow \text { Controller } \rightarrow \quad \text { JSP } \\
\\
\rightarrow \text { User }\end{array}$ \\
\hline
\end{tabular}

Pembahasan yang kedua adalah pemisahan kode controller dari presentasi. Perbedaan tersebut bisa di lihat tabel di bawah ini :

Tabel 5

Perbandingan Kode Controller dan Presentasi

\begin{tabular}{|c|c|c|}
\hline Lapisan & Model 1 & \multicolumn{1}{|c|}{ Model 2 } \\
\hline Presentasi & Validasi data & Tampil data \\
\hline
\end{tabular}

\begin{tabular}{|l|l|l|}
\hline Lapisan & \multicolumn{1}{|c|}{ Model 1 } & \multicolumn{1}{|c|}{ Model 2 } \\
\hline & Manipulasi & Pesan user \\
& data \\
& Dispatch \\
& Tampil data & \\
& Pesan user & \\
\hline Controller & - & $\begin{array}{l}\text { Validasi data } \\
\text { Manipulasi data } \\
\end{array}$ \\
& & Dispatch \\
\hline
\end{tabular}

Perbedaan yang ketiga adalah terletak pada pengembangan aplikasi. Perbedaan tersebut bisa di lihat tabel di bawah ini :

Tabel 6

Perbandingan Pengembangan Aplikasi

\begin{tabular}{|c|c|}
\hline Model 1 & Model 2 \\
\hline Berbasis Halaman & Model View \\
JSP & Controller \\
\hline
\end{tabular}

\section{Model 2 Dengan Framework Struts2}

Diagram sequence di atas berbeda dengan diagram sequence Model 2 sebelumnya. Dalam gambar tersebut memiliki sebuah struts.xml sebagai controller dan SuplierAction sebagai kelas action. Berikut ini daftar file aplikasi yang dibutuhkan :

\section{Tabel 7}

Daftar File Aplikasi Dengan Struts2

\begin{tabular}{|l|l|}
\hline \multicolumn{1}{|c|}{ Lapisan } & \multicolumn{1}{c|}{ File } \\
\hline Lapisan & Menu.jsp \\
Presentasi & SaveSuplier.jsp \\
\hline
\end{tabular}




\begin{tabular}{|c|c|}
\hline & $\begin{array}{l}\text { UpdateSuplier.jsp } \\
\text { DeleteSuplier.jsp } \\
\text { ViewSuplier.jsp } \\
\text { InformasiSave.jsp } \\
\text { InformasiUpdate.jsp } \\
\text { InformasiDelete.jsp }\end{array}$ \\
\hline $\begin{array}{l}\text { Lapisan } \\
\text { Controller }\end{array}$ & struts.xml \\
\hline Lapisan Aplikasi & $\begin{array}{l}\text { SuplierAction.java } \\
\text { Suplier.java } \\
\text { ManagerDB.java } \\
\text { xx-validation.xml }\end{array}$ \\
\hline
\end{tabular}

Berdasarkan tabel di atas, terlihat adanya file struts.xml sebagai controller yang digunakan untuk mengatur alur aplikasi. Semua event dari pengguna akan ditangani oleh controller.

\section{KESIMPULAN}

Dari hasil eksplorasi model interaksi web pada teknologi Java didapatkan beberapa kesimpulan. Berikut ini beberapa kesimpulan yang didapatkan dari hasil penelitian:

1. Model 1 merupakan model pengembangan aplikasi web berbasis halaman JSP sedangkan Model 2 sudah memisahkan logika controller dari layer presentasi dan membentuk layer sendiri yaitu layer controller.

2. Model 2 terlihat lebih modular dibandingkan dengan Model 1 dengan adanya tambahan objek program sehingga menambah pekerjaan dalam pembuatan programnya.

3. Pemisahan logika presentasi dari lapisan presentasi memudahkan program untuk dibaca dan dipelajari.

4. Pembuatan aplikasi dengan menggunakan framework tidak terlalu membutuhkan pengkodean, untuk beberapa fitur aplikasi bisa dilakukan dengan cara konfigurasi sehingga bisa lebih produktif dalam mengembangkan aplikasi. Namun pengembang harus memahami framework yang akan digunakan untuk pengembangan aplikasinya.

\section{DAFTAR RUJUKAN}

[1] Pressman, R.S., dan Lowe, D., Web Engineering: A practitioners approach. McGraw-Hill. New-York. 2009.

[2] Chung, S. dan Lee, Y. Modeling Web Applications Using Java And XML Related Technologies. Proceedings of the 36th Hawaii International Conference on System Sciences (HICSS'03). IEEE. 2002.

[3] Brereton, P., Budgen, D., dan Hamilton, G., Hypertext: The Next Maintenance Mountain. IEEE Computer. December 1998. pp. 49-55.

[4] Sukendar, Ade. Model Interaksi Web Pada Teknologi Java. Universitas Pasundan, Bandung, April 2010. 
[5] About Dynamic Content. Data diperoleh melalui internet:

http://www.adobepress.com/articles/

article. $a s p ? p=31062 \&$ seqNum $=3$.

Diunduh pada Januari 2010.

[6] Horstmann, C., Core JSP. San Jose, Prentice Hall. 2000.

[7] Jendrock, E., dkk. The Java EE 5 Tutorial, Third Edition : For Sun Java System Application Server Platform Edition 9. California, Sun Microsystems, Inc. 2006.

[8] Falkner, J. dan Jones, K., Servlets and JavaServer Pages ${ }^{\mathrm{TM}}$ : The J2EE ${ }^{\mathrm{TM}}$ Technology Web Tier. Boston, Pearson Education. 2006.

[9] Integrating Servlet and JSP : The Model View Controller (MVC). Data diambil dari internet: J2EE training from the author: http://courses.coreservlets.com/. Diunduh pada Januari 2010.
[10] Kurniawan, B., Struts2 Design and Programming: A Tutorial. Brainy Software. 2008.

[11] Newton, D., Apache Struts 2 Web Application Development. BirminghamMumbai, Packt Publishing. 2009.

[12] Roughley, I., Practical Apache Struts2 web 2.0 Projects. USA, Apress. 2007.

[13] Turner, J. dan Berdell, J., Struts Kick Start. Pearson Education. 2003.

[14] Wijono, S. H., Suharto, H., Wijono, M. S., Pemrograman Java Servlet dan JSP dengan NetBeans. Yogyakarta, Penerbit Andi. 2006.

[15] JSP Architecture. Data Diperoleh dari internet:

http://www.brainopolis.com/jsp/jspArchite cture.html. Diunduh pada Januari 2010. 